\title{
Growth and Yield of Pea (Pisum sativum L.) cv. Azad P-1 as Influenced by NADEP Composts Prepared by Using Different Raw Materials
}

\author{
Vipin Kumar ${ }^{1 *}$, Arvind Kumar ${ }^{1}$, M.K. Singh ${ }^{1}$, Mukesh Kumar ${ }^{1}$ and Uttam Kumar ${ }^{2}$ \\ ${ }^{1}$ SVP University of Agriculture and Technology, Meerut (UP), India \\ ${ }^{2}$ National Dairy Research Institute (NDRI), ICAR, Karnal, Haryana, India \\ *Corresponding author
}

\section{A B S T R A C T}

\section{Keywords}

Pisum sativum,

Growth and yield,

NADEP compost,

NPK.

Article Info

Accepted:

17 September 2017

Available Online:

10 November 2017
The present investigation "Growth and Yield of Pea (Pisum sativum L.) cv. Azad P-1 as Influenced by NADEP Composts" comprised of eleven treatments consisting the different levels of NPK, and different type NADEP compost prepared by different raw materials. During the experimentation, growth character and yield characters were recorded. The germination of pea cv. Azad P-1, Seeds became faster with T6 [20:40:50 kg/ha of NPK + $10 \mathrm{t}$ NADEP (1)] treatment and there after the flowering, fruiting also increased progressively in the same treatment. The T1 [(10:20:25 kg/ha of NPK + $10 \mathrm{t}$ NADEP (1)] treatment exhibited the maximum yield/ha followed by T6. A comparative study of the present findings led to the conclusion that sowing of pea with the application of NADEP (1) compost @ $10 \mathrm{t} / \mathrm{ha}$ and NPK @ 10:25:25kg/ha was found most effective to best growth of pea crop under western plain zone of UP.

\section{Introduction}

Pea (Pisum sativum L.) is one of the important vegetables in the world and ranks among the top 10 vegetable crops (Ref./ in the world?). Pea is commonly used in human diet throughout the world and it is rich in protein (21-25\%), carbohydrates, vitamin A and C, $\mathrm{Ca}$, phosphorous and has high levels of amino acids lysin and trypophan (Bhat et al., 2013). Its cultivation maintains soil fertility through biological nitrogen fixation in association with symbiotic rhizobium prevalent in its root nodules and thus play a vital role in fostering sustainable agriculture (Negi et al., 2006). Therefore, apart from meeting its own requirement of nitrogen, peas are known to leave behind residual nitrogen in soil 50-60 $\mathrm{kg} / \mathrm{ha}$ (Kanwar et al., 1990).

Chemical fertilizers are needed to get good crop yields but their abuse and overuse can be harmful for the environment and their cost cannot make economic and profitable agricultural products (Bobade et al., 1992). The increased use of chemicals under intensive cultivation has not only contaminated the ground and surface water but has also distributed the harmony existing among the soil, plant and microbial population (Bahadur et al., 2006). Biofertilizers or compost on the other hand 
are cost-effective and renewable source of plant nutrients to supplement the parts of chemical fertilizers. Biofertilizers are known to play an important role in increasing availability of nitrogen and phosphorus besides improving biological fixation of atmospheric nitrogen and enhance phosphorus availability to crop (Bhat et al., 2013). A judicious use of organic manures and biofertilizers may be effective not only sustaining crop productivity and in soil health, but also in supplementing chemical fertilizers of crop (Jaipal et al., 2011).

Incorporation of organic fertilizers into soil causes a large and rapid increase in the soil microbial biomass (Ghoshal and Singh, 1995; Heinze et al., 2010), which forms only a small fraction of soil organic matter. However the soil microbial biomass plays an important role in nutrient cycling and plant nutrition, due to its fast turnover (Jenkinson and Ladd, 1981). For this reason, some studies have found a close relationship between the soil microbial biomass and crop yields under greenhouse conditions (Chen et al., 2000) as well as under field conditions (Insam et al., 1991; Goyal et al., 1992; Khan and Joergensen, 2006; Mandal et al., 2007). However, this relationship has not always been observed (Nilsson et al., 2005).

\section{Materials and Methods}

The present investigation entitled "Response of vermi-compost on growth and yield of pea (Pisum sativum L.) cv. Azad P-1" was carried out during 2013- 2014 at Horticultural Research Centre, of Sardar Vallabhbhai Patel University of Agricultural \& Technology, Meerut to standardize the optimum dose and formulation of NADEP compost for obtaining best growth, flowering and production of yield. The experiment comprised of eleven treatments consisting of different type of NADEP compost made from different waste materials (Table 1) in combination with two levels of NPK, and the combination of was laid out in randomized block design with three replication. The treatments are as,

T1: $10: 20: 25 \mathrm{~kg} / \mathrm{ha}$ of NPK + $10 \mathrm{t}$ NADEP (1) T2: $10: 20: 25 \mathrm{~kg} / \mathrm{ha}$ of NPK + $10 \mathrm{t}$ NADEP (2) T3: 10:20:25 kg/ha of NPK + 10 t NADEP (3) T4: $10: 20: 25 \mathrm{~kg} / \mathrm{ha}$ of NPK + $10 \mathrm{t}$ NADEP (4) T5: $10: 20: 25 \mathrm{~kg} / \mathrm{ha}$ of NPK + $10 \mathrm{t}$ NADEP (5) T6: $20: 40: 50 \mathrm{~kg} / \mathrm{ha}$ of NPK + $10 \mathrm{t}$ NADEP (1) T7: $20: 40: 50 \mathrm{~kg} / \mathrm{ha}$ of NPK + $10 \mathrm{t}$ NADEP (2) T8: $20: 40: 50 \mathrm{~kg} / \mathrm{ha}$ of NPK + $10 \mathrm{t}$ NADEP (3) T9: $20: 40: 50 \mathrm{~kg} / \mathrm{ha}$ of NPK + $10 \mathrm{t}$ NADEP (4) T10: $20: 40: 50 \mathrm{~kg} / \mathrm{ha}$ of NPK + $10 \mathrm{t}$ NADEP (5)

T11: 20:40:50 $\mathrm{kg} / \mathrm{ha}$ of NPK Through chemical fertilizers (Control)

Basal application of $1 / 2$ dose of $\mathrm{N}$ in the form of urea, full dose of $\mathrm{P}$ in the form of single super phosphate (S.S.P.) and $\mathrm{K}$ in the form of murate of potash, and NADEP compost as per the nutrient status was given with broad cast method. Rest half dose of $\mathrm{N}$ was applied 30 days after germination. During the experimentation, Five plants under each treatment combination were randomly selected and tagged for recording the observation on growth and yield characters (whenever required).

\section{Results and Discussion}

\section{Growth of Pea}

The germination of pea cv. Azad P-1, Seeds became faster (11 days) with T6 [20:40:50 $\mathrm{kg} / \mathrm{ha}$ of NPK $+10 \mathrm{t}$ NADEP (1)] treatment and there after the flowering, fruiting also increased progressively in the same treatment. Optimum dose of Phosphorus and potassium had significant effect on vine length while their interaction indicated non-significant differences among the treatment means. The result indicates that the vine length 
significantly increased with the increasing rate of phosphorus and potassium up to $69 \mathrm{~kg}$ $\mathrm{P}_{2} \mathrm{O}_{5}$ and $100 \mathrm{~kg} \quad \mathrm{~K}_{2} \mathrm{O} \mathrm{ha}^{-1}$ respectively (Akhtar et al., 2003). The performance of pea with respect to germination and nodulation was influenced by the temperature, rainfall, humidity etc. Lopes et al., (1996) reported that an increase in levels of vermicompost up to $10 \mathrm{t} / \mathrm{ha}$ significantly increased nodulation and dry matter yield of cowpea over rest of the treatments.

Levels of NADEP compost also had significant effect on days to flowering and fruiting. Minimum days taken to flowering (44.00) and fruiting (63.7) were recorded in T6 (20:40:50 kg/ha of NPK + $10 \mathrm{t}$ NADEP (1)) followed by 44.3 days and 65.3 for flowering and fruiting respectively, were taken by T210:20:25 kg/ha of NPK + $10 \mathrm{t}$ NADEP (2) and maximum (45.7) days to flowering and fruiting (68.7) were taken by T11 (20:40:50 kg/ha of NPK (Control). The deficiency of major nutrients stunted the plant growth, resulting the maximum days taken to flowering. Very optimum dose of NPK reduce the days taken to flowering up to a certain limit and vice versa. Similar results were coated by Naeem et al., (2002) for chilli.
Maximum number of branches (22.0) and length of plant (77.00) were also found with the T6 [20:40:50 kg/ha of NPK + $10 \mathrm{t}$ NADEP (1)] whereas these were minimum 14.7, and 55.7 for number of branches and length of plan respectively in the controlled treatment T11 (20:40:50 kg/ha of NPK). ElBeheldi et al., (1985), Abdel-Ghaffar and Mohamed (1992) found that the growth parameters (number of branches and length of plant etc.) of pea cultivars was significantly affected by number of nodulation /plant, which is increased by inoculation treatments through organic compost.

Data recorded on yield characters are presented on table 2 data indicate that, NADEP-compost levels also influenced the number of pods per plant. The highest pod number (10.00) was obtained with T6 (20:40:50 kg/ha of NPK + 10 t NADEP (1)) treatment under the present study and it was minimum (6.5) in controlled treatment T11 (20:40:50 kg/ha of NPK). The plants treated with different combinations of NPK and NADEP compost results in to higher length of pods. Similar results were reported by Nadeem et al., (2003) and Parsad et al., (2005).

Table.1 Nutrients composition of compost obtained from different types NADEP composting

\begin{tabular}{|c|c|c|c|c|c|c|}
\hline $\begin{array}{l}\text { Sl. } \\
\text { No }\end{array}$ & Treatments & $\begin{array}{l}\mathbf{N} \\
(\%)\end{array}$ & $\begin{array}{l}P_{2} \mathrm{O}_{5} \\
(\%)\end{array}$ & $\mathrm{K}_{2} \mathrm{O}(\%)$ & pH & $\mathrm{EC}(\mathrm{ms})$ \\
\hline $\mathrm{N}_{1}$ & $\begin{array}{l}1500 \mathrm{~kg} \text {. Dung }+420 \mathrm{~kg} \text {. Dry cuttings of Parthenium }+1400 \\
\mathrm{~kg} \text {. Soil }+2000 \text { lit. Water }\end{array}$ & 2.18 & 0.41 & 1.42 & 8.56 & 0.355 \\
\hline $\mathbf{N}_{2}$ & $\begin{array}{l}1300 \mathrm{~kg} . \text { Dung }+720 \mathrm{~kg} \text {. green cuttings of parthenium }+1200 \\
\mathrm{~kg} \text {. Soil }+1800 \text { lit. Water }\end{array}$ & 2.37 & 0.53 & 1.79 & 9.04 & 0.480 \\
\hline $\mathbf{N}_{3}$ & $\begin{array}{l}1500 \mathrm{~kg} \text {. Dung }+420 \mathrm{~kg} \text {. Dry cuttings of Bhang }+1400 \mathrm{~kg} \text {. } \\
\text { Soil }+2000 \text { lit. Water }\end{array}$ & 1.24 & 0.23 & 1.24 & 8.56 & 0.387 \\
\hline $\mathbf{N}_{4}$ & $\begin{array}{l}1300 \mathrm{~kg} . \text { Dung }+720 \mathrm{~kg} \text {. green cuttings of Bhang }+1200 \mathrm{~kg} \text {. } \\
\text { Soil }+1800 \text { lit. Water }\end{array}$ & 1.69 & 0.10 & 1.08 & 8.00 & 0.402 \\
\hline $\mathbf{N}_{5}$ & $\begin{array}{l}1500 \mathrm{~kg} \text {. Dung }+420 \mathrm{~kg} \text {. Waste material (Crop residue, } \\
\text { leaves etc.) }+1400 \mathrm{~kg} \text {. Soil }+2000 \text { lit. Water }\end{array}$ & 2.10 & 0.42 & 1.89 & 8.69 & 0.410 \\
\hline
\end{tabular}


Table.2 Effect of NADEP-compost on yield characters of Pea (Pisum sativam L.)

\begin{tabular}{|c|c|c|c|c|c|c|c|c|c|c|c|}
\hline $\begin{array}{l}\text { SI } \\
\text { No }\end{array}$ & Treatment & $\begin{array}{l}\text { Days to } \\
\text { germination }\end{array}$ & $\begin{array}{l}\text { Days to } \\
\text { flowering }\end{array}$ & $\begin{array}{l}\text { Days to } \\
\text { fruiting }\end{array}$ & $\begin{array}{l}\text { No. of } \\
\text { branches }\end{array}$ & $\begin{array}{l}\text { Length } \\
\text { of } \\
\text { plant }\end{array}$ & $\begin{array}{l}\text { No. of } \\
\text { pod/ } \\
\text { plant }\end{array}$ & $\begin{array}{l}\text { No. of } \\
\text { seed } \\
\text { per } \\
\text { plant }\end{array}$ & $\begin{array}{l}\text { Length } \\
\text { of pod }\end{array}$ & $\begin{array}{l}\text { Wt. } \\
\text { of } \\
\text { pod }\end{array}$ & $\begin{array}{l}\text { Yield } \\
\text { ton/ha }\end{array}$ \\
\hline 1 & $10: 20: 25 \mathrm{~kg} / \mathrm{ha}$ of NPK $+10 \mathrm{t}$ NADEP (1) & 16.0 & 46.3 & 67.3 & 19.0 & 67.3 & 9.0 & 6.3 & 5.2 & 6.0 & 11.8 \\
\hline 2 & $10: 20: 25 \mathrm{~kg} / \mathrm{ha}$ of NPK + $10 \mathrm{t}$ NADEP (2) & 14.0 & 44.3 & 65.3 & 15.0 & 67.0 & 8.7 & 6.0 & 5.2 & 5.4 & 10.5 \\
\hline 3 & $10: 20: 25 \mathrm{~kg} / \mathrm{ha}$ of NPK + $10 \mathrm{t}$ NADEP (3) & 11.7 & 47.0 & 66.0 & 15.0 & 62.3 & 9.7 & 4.3 & 4.4 & 5.4 & 10.6 \\
\hline 4 & $10: 20: 25 \mathrm{~kg} / \mathrm{ha}$ of NPK + $10 \mathrm{t}$ NADEP (4) & 14.0 & 47.3 & 67.3 & 15.3 & 64.7 & 6.0 & 6.3 & 4.5 & 5.7 & 11.0 \\
\hline 5 & $10: 20: 25 \mathrm{~kg} / \mathrm{ha}$ of NPK + $10 \mathrm{t}$ NADEP (5) & 13.0 & 44.3 & 65.7 & 21.7 & 69.3 & 8.7 & 7.7 & 5.1 & 5.7 & 11.0 \\
\hline 6 & $20: 40: 50 \mathrm{~kg} / \mathrm{ha}$ of NPK + $10 \mathrm{t}$ NADEP (1) & 11.0 & 44.0 & 63.7 & 22.0 & 77.0 & 10.0 & 7.0 & 5.1 & 6.4 & 12.0 \\
\hline 7 & $20: 40: 50 \mathrm{~kg} / \mathrm{ha}$ of NPK + $10 \mathrm{t}$ NADEP (2) & 12.7 & 48.7 & 69.7 & 15.3 & 70.0 & 9.3 & 6.0 & 4.1 & 6.0 & 11.6 \\
\hline 8 & $20: 40: 50 \mathrm{~kg} / \mathrm{ha}$ of NPK + $10 \mathrm{t}$ NADEP (3) & 12.0 & 49.3 & 67.3 & 15.3 & 70.7 & 7.7 & 6.0 & 3.8 & 5.7 & 11.3 \\
\hline 9 & $20: 40: 50 \mathrm{~kg} / \mathrm{ha}$ of NPK + $10 \mathrm{t}$ NADEP (4) & 12.3 & 49.7 & 68.7 & 16.3 & 72.7 & 8.0 & 4.7 & 4.2 & 5.8 & 11.6 \\
\hline 10 & $20: 40: 50 \mathrm{~kg} / \mathrm{ha}$ of NPK + $10 \mathrm{t}$ NADEP (5) & 13.0 & 52.0 & 71.3 & 15.3 & 56.0 & 6.7 & 4.3 & 4.4 & 5.0 & 10.6 \\
\hline \multirow[t]{6}{*}{11} & $20: 40: 50 \mathrm{~kg} / \mathrm{ha}$ of NPK & 12.3 & 45.7 & 66.7 & 14.7 & 55.7 & 6.5 & 4.2 & 4.0 & 4.8 & 9.8 \\
\hline & CD $(1 \%)$ & 1.266 & 3.307 & 3.507 & 1.781 & 3.761 & 1.72 & 1.412 & 0.944 & 0.459 & 1.299 \\
\hline & CD (5\%) & 0.928 & 2.425 & 2.571 & 1.306 & 2.758 & 1.261 & 1.036 & 0.692 & 0.351 & 0.952 \\
\hline & SE (m) & 0.315 & 0.882 & 0.872 & 0.443 & 0.935 & 0.428 & 0.351 & 0.235 & 0.569 & 0.469 \\
\hline & SE (d) & 0.445 & 1.163 & 1.233 & 0.626 & 1.322 & 0.605 & 0.496 & 0.332 & 1.215 & 0.625 \\
\hline & $\mathrm{CV}$ & 4.221 & 3.02 & 2.247 & 4.534 & 2.418 & 9.018 & 10.45 & 8.853 & 3.661 & 5.076 \\
\hline
\end{tabular}



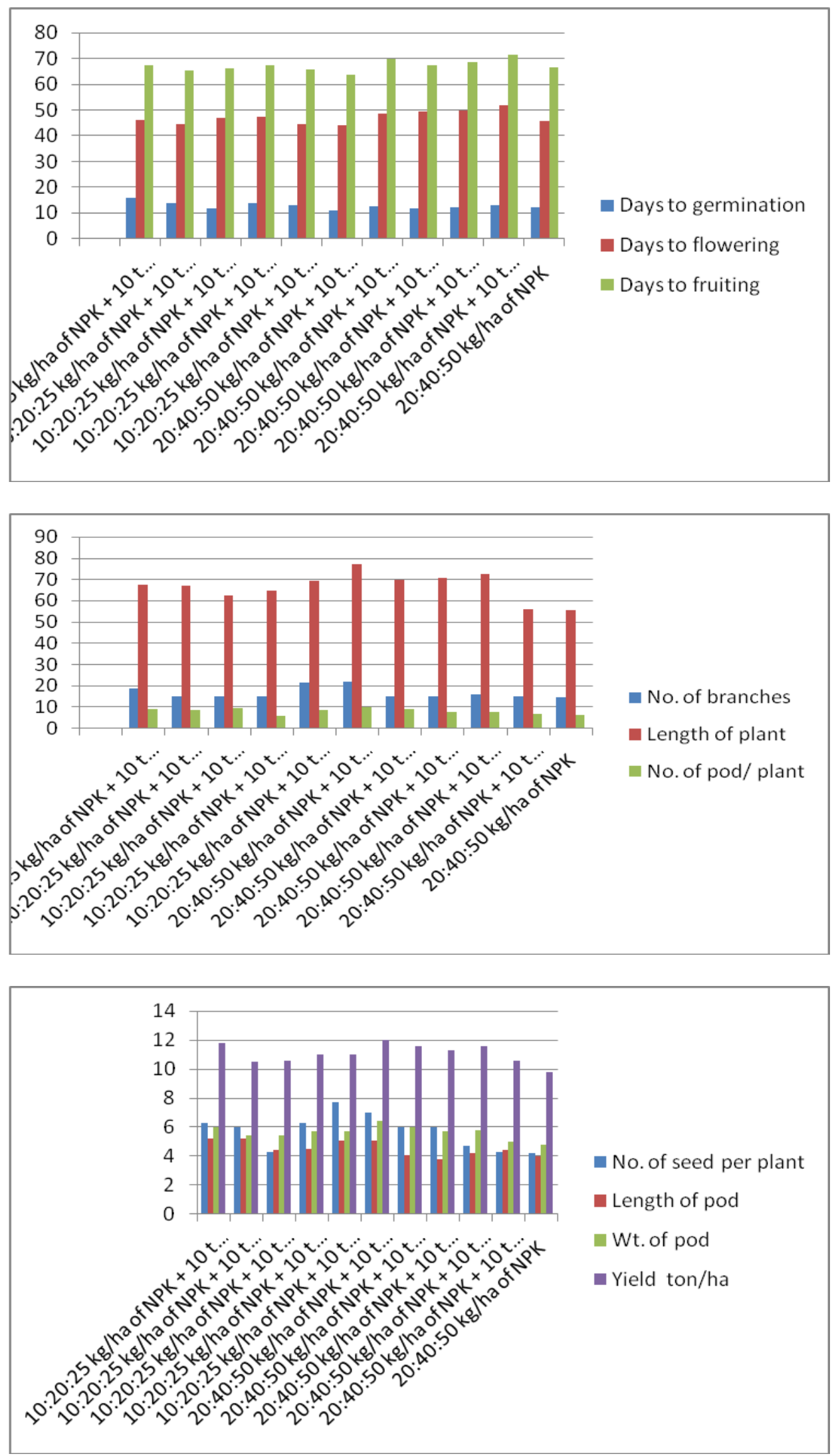


\section{Yield of pea}

An increasing trend in number of seed per pod was observed in pea with increasing levels of NADEP compost, and the maximum being under $(20: 40: 50 \mathrm{~kg} / \mathrm{ha}$ of NPK $+10 \mathrm{t}$ NADEP (5) level whereas it was minimum (4.2) in controlled treatment T11 (20:40:50 $\mathrm{kg} / \mathrm{ha}$ of NPK). Length of pod (5.2) was

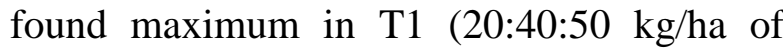
NPK + 10 t NADEP (5) followed by T6 (5.1) and minimum (4.0) was in T11 (20:40:50 $\mathrm{kg} / \mathrm{ha}$ of NPK). Weight of pod was found maximum (6.4) in T6 [20:40:50 kg/ha of NPK +10 t NADEP (1)] and minimum (4.8) in T11 (20:40:50 kg/ha of NPK). Proper nutrients promote vigorous growth of the plant which ultimately increase the size of pod as well as seed which confirms the observation of Waseem et al., (2008).

NADEP compost doses significantly increased the yield per hectare over control. Having produced the maximum yield per hectare (12.0) found under T6 (20:40:50 $\mathrm{kg} / \mathrm{ha}$ of NPK + $10 \mathrm{t}$ NADEP (1) treatment followed by obtained the top rank. A comparative study of the present findings led to the conclusion that sowing of pea with the application of NADEP compost @ (20:40:50 $\mathrm{kg} / \mathrm{ha}$ of NPK $+10 \mathrm{t}$ NADEP (1) $\mathrm{kg} / \mathrm{ha}$ was found most effective to best growth of pea crop under North west plain zones of Uttar Pardesh. Vimla and Natrajan (2000) reported a combination of organic and organic fertilizers at the optimum dose significantly increased the yield and yield attributing characters. Jaipaul et al., (2011) and Mishra et al., (2010) had reported the similar findings in their experiments.

The organic source applied to the soil through biofertilizers have influenced the soil nutrient availability through better microbial activities in fixing atmospheric $\mathrm{N}$ and releasing the nutrients from the soil and help in the process of absorption of ample nutrients and its utilization by the plants due to influence on yield.

The above results showed that the pure chemical could not result in highest yield and quality. The integration of biofertilizers along with chemicals in an appropriate dose not only has a positive effect on the yield attributes of pea and gives highest net returns but also Increasing soil fertility status and ecofriendly as well (Bhattarai et al., 2003).

\section{References}

Abdel- Ghaffar SA and Mohamed FI (1992) Response of pea (Pisum sativum L.) to inoculation and $\mathrm{N}$-fertilization, Journal of Agricultural sciences, Mansoura Univ., 17 (3): 619 - 626.

Akhtar N Amjad M and Anjum MA (2003) Growth and yield response of pea (Pisum sativum L.) crop to phosphorus and potassium application (Pakistan Journal of Agriculture), 40: 3-4.

Bahadur A, Singh J, Singh KP, Upadhyay AK and Rai M (2006) Effect of organic amendments and biofertilizers on growth, yield and quality attributes of Chinese cabbage (Brassica pekinensis), Indian Journal of Agricultural Sciences, 76: 596-598.

Bhat TA, Gupta M, Ganai MA, Ahanger RA and Bhat HA (2013) Yield, soil health and nutrient utilization of field pea (Pisum sativum L.) as affected by phosphorus and Biofertilizers under subtropical conditions of Jammu, International journal of modern plant and animal science, 1(1):1-8.Biology and Fertility of Soils 19, 231-238.

Bhttarai RK, Singh LN and Singh RKK (2003) Effect of integrated nutrient management on yield attributes and economics of pea (Pisum sativum), Indian Journal of Agricultual Sciences, 73(4):219-220. 
Bobade KP, Kolte SO, Patil BG (1992) Affectivity of cyanobacterial technology for transplanted rice, Phykos, 31: 33-35.

Chen, G.C., He, Z.L., Huang, C.Y., 2000. Microbial biomass phosphorus and its significance in predicting phosphorus availability in red soils. Communications in Soil Science and Plant Analysis 31, 655-667.

El-Beheidi MA, Gad AA, El-Sawah MH, and El Hady HM (1985) Effect of inoculation with Rhizobium leguminosarum and nitrogen fertilization on pea plants. Zoldsegtermesztesi Kutato Intezet Bulletinje 18: 17-25.

Ghoshal, N., Singh, K.P., 1995. Effects of farmyard manure and inorganic fertilizer on the dynamics of soil microbial biomass in a tropical dryland agroecosystem.

Goyal, S., Mishra, M.M., Hooda, I.S., Singh, R., 1992. Organic matter-microbial biomass relationships in field experiments under tropical conditions: effects of inorganic fertilization and organic amendments. Soil Biology and Biochemistry 24, 1081-1084.

Heinze, S., Raupp, J., Joergensen, R.G., 2010. Effects of fertilizer and spatial heterogeneity in soil $\mathrm{pH}$ on microbial biomass indices in a long-term field trial of organic agriculture. Plant and Soil 328, 203-215.

Insam, H., Mitchell, C.C., Dormaar, J.F., 1991. Relationship of soil microbial biomass and activity with fertilization practice and crop yield of three ultisols. Soil Biology and Biochemistry 23, 459464.

Jaipaul, Sharma S, Dixit AK and Sharma AK (2011) Growth and yield of capsicum and garden pea as influenced by organic manures and biofertilizers, Indian J. of Agricultural Sciences 81(7): 637-642.
Jenkinson, D.S., Ladd, J.N., 1981. Microbial biomass in soil: measurement and turnover. In: Paul, E.A., Ladd, J.N. (Eds.), Soil Biochemistry, vol. 5. Dekker, New

Kanwar JS (1990) Punjab Veg. Grower, 25: 12-15. Karaine V and Singh VP (2009) Effect of rhizobial inoculation on growth, yield, nodulation and biochemical characters of vegetable pea (Pisum sativum), Acta Agronomics Hungarica, 57(1): 47-56.

Khan, K.S., Joergensen, R.G., 2006. Microbial $\mathrm{C}, \mathrm{N}$, and $\mathrm{P}$ relationships in moisture stressed soils of Potohar, Pakistan. Journal of Plant Nutrition and Soil Science 169, 494-500.

Lopes, A. J., Stamford, N.P., Figueired, M.V.B., Burity, N.A. and Ferraz, E.B.(1996). Effect of vermicompost, mineral nitrogen and mineralizing agent on $\mathrm{N}$ fixation and yield in cowpea. Revista - Brasileira - de-ciencia-dosolo, 20 : 55-62.

Mandal, A., Patra, A.K., Singh, D., Swarup, A., Masto, R.E., 2007. Effect of longterm application of manure and fertilizer on biological and biochemical activities in soil during crop development stages. Bioresource Technology 98, 3585-3592.

Mishra A, Prasad K and Rai G (2010) Effect of Bio-fertilizer Inoculations on Growth and Yield of Dwarf Field Pea (Pisum sativum L.) in Conjunction with Different Doses of Chemical Fertilizers, Journal of Agronomy, 9: 163-168.

Naeem, N.M. Irfan, J. Khan, G. Nabi N. Muhammad and N. Badshah, 2002. Influence of various levels of nitrogen and phosphorus on growth and yield of chilli (Capsicum annum L.) Asian J. Pl Sci. 1: 599-601.

Negi S, sing RV and Dwivedi OK (2006) Effect of Biofertilizers, nutrient sources and lime on growth and yield of garden 
pea, Legume research, 29 (4): 282-285.

Nilsson, K.S., Hyvoenen, R., Ågren, G.I., 2005. Using the continuous-quality theory to predict microbial biomass and soil organic carbon following organic amendments. European Journal of Soil Science 56, 397-405.

Prasad Kader, Kumar Sanjay, Pyare JPS (2005). Effect of FYM and biofertilizers in conjuction with inorganic fertilizers on growth, yiel and profit of chick pea (Cicer arietinum L.). Plant achieves
5(2): 609-612.

Vimala B and Natarajan S (2000) Effect of nitrogen, phosphorus and biofertilizers on pod characters and yield and quality in pea (Pisum sativum L. Spp. Hortense), Indian Hort., 48(1-6): 60-63.

Waseem, K., q.m. Kamran and M.S.Jilani. 2008. Effect of different levels of nitrogen on the growth and yield of Cucumber (Cucumis sativus L.). J. Agric. Res., 259-266. York, pp. 415471.

\section{How to cite this article:}

Vipin Kumar, Arvind Kumar, M.K. Singh, Mukesh Kumar and Uttam Kumar. 2017. Growth and Yield of Pea (Pisum sativum L.) cv. Azad P-1 as Influenced by NADEP Composts Prepared by Using Different Raw Materials. Int.J.Curr.Microbiol.App.Sci. 6(11): 2260-2267. doi: https://doi.org/10.20546/ijcmas.2017.611.268 